\title{
Statistical Prediction Model for Terrestrial Gamma Radiation Measurements in an Area Based on Geological Formations and Soil Types
}

\author{
Hamman Tukur Gabdo ${ }^{1 *}$, Bello Yusuf Idi ${ }^{2}$ \\ ${ }^{1}$ Department of Physics, School of Sciences, Federal College of Education Yola, Nigeria. \\ ${ }^{2}$ Department of Physics, Faculty of Science, Adamawa State University Mubi, Nigeria. \\ * Corresponding author. Email: ghtukur@fceyola.edu.ng \\ Manuscript submitted March 2, 2016; accepted June 12, 2016. \\ doi: 10.17706/ijapm.2016.6.3.95-103
}

\begin{abstract}
This study aims to produce a model for the prediction and estimation of unmeasured terrestrial gamma dose rate (TGDR) using statistical analysis based on geological formation and soil type. The measurements of TGDR were conducted in the Pahang state Malaysia, with a total of 640 measured points that covers all geological formations and soil types in the state. The measurements were taken $1 \mathrm{~m}$ above the soil surface using Ludlum 19 gamma ray $(\mu \mathrm{R})$ meter. The measured gamma dose rates ranged from 26 nGy h-1 to $750 \mathrm{nGy} \mathrm{h}^{-1}$ with a mean value of $176 \mathrm{nGy} \mathrm{h}^{-1}$. The data have been normalized to fit a normal distribution. Significance testing was conducted among all geological formations and soil types, using one way analysis of variance (ANOVA). The results indicated strong significant differences due to the different geological formations and soil types present in the State. Pearson Correlation was used to measure the relations between gamma dose rate based on geological formation and soil type $\left(G_{D}, S_{D}\right)$ with the gamma dose rate based on geological formation $\left(G_{D}\right)$ or gamma dose rate base on soil type $\left(S_{D}\right)$. A very good correlation $(88.3 \%)$ was found between $G_{D}, S_{D}$ and $G_{D}$ or $G_{D}, S_{D}$ and $S_{D}$. A total of 85 pairs of geological formations and soil types were used to derive the statistical contribution of geological formations and soil types to gamma dose rates. The percentage contribution of the gamma dose rate from geological formation and soil type were found to be 0.580 and 0.311 , respectively. The null hypotheses were accepted for $88 \%$ of examined data, therefore, the model could be used to predict gamma dose rates based on geological formation and soil type information.
\end{abstract}

Key words: Geological formation, gamma dose rate, soil type, statistical prediction model.

\section{Introduction}

Various measurements were made on terrestrial gamma radiation (TGR) measurements in different parts of the world, all in the view to determine the values for TGR in the environment and the corresponding heath implications to the populace.

Most of the radioactivity in the terrestrial environment, whether it is natural or man-made, binds to the components of the soil [1]. Therefore, all exposures that originate from soil are potentially important for the purpose of radiation risk assessment. Higher radioactivity in soil samples may be linked to the contribution of the parent materials that constitute the soil type [2]. For instance, soil derived from granite rocks which originates from acid intrusive geological formation will have a higher radioactivity than the soil from the 
other rock types. This is the reason why peat soil, which is an accumulation of partially decayed vegetation has lower radioactivity [3] and [4].

Radioactivity levels vary greatly depending on soil type and the mineral make-up. The higher concentrations of uranium, thorium and potassium are associated with soil developed from acid intrusive rocks. Most uranium is associated with the phosphate sands and clays originating from acid intrusive geological formations [5].

Soil acts as a channel for the transfer of radionuclides to plants and animals and hence, it is the basic indicator of the radiological status of the environment. Soil that has a high radiation dose levels are usually caused by the presence of some minerals such as monazite [6].High readings are also due to the contribution of radioactivity from the soil parent material [7].

Relationships between terrestrial gamma radiation dose rate, soil types and the underlying geological formation has been investigated previously [8]-[11]. Statistical evaluations of the results were carried out.

The results were however obtained after an extensive, tedious and expensive field work. The prediction model is therefore required in other to predict terrestrial gamma dose rate with a minimum field work.

In this study, a prediction model base on the geological formations and soil types was statistically evaluated using the data obtained in Pahang state Malaysia [8].

\section{Materials and Methods}

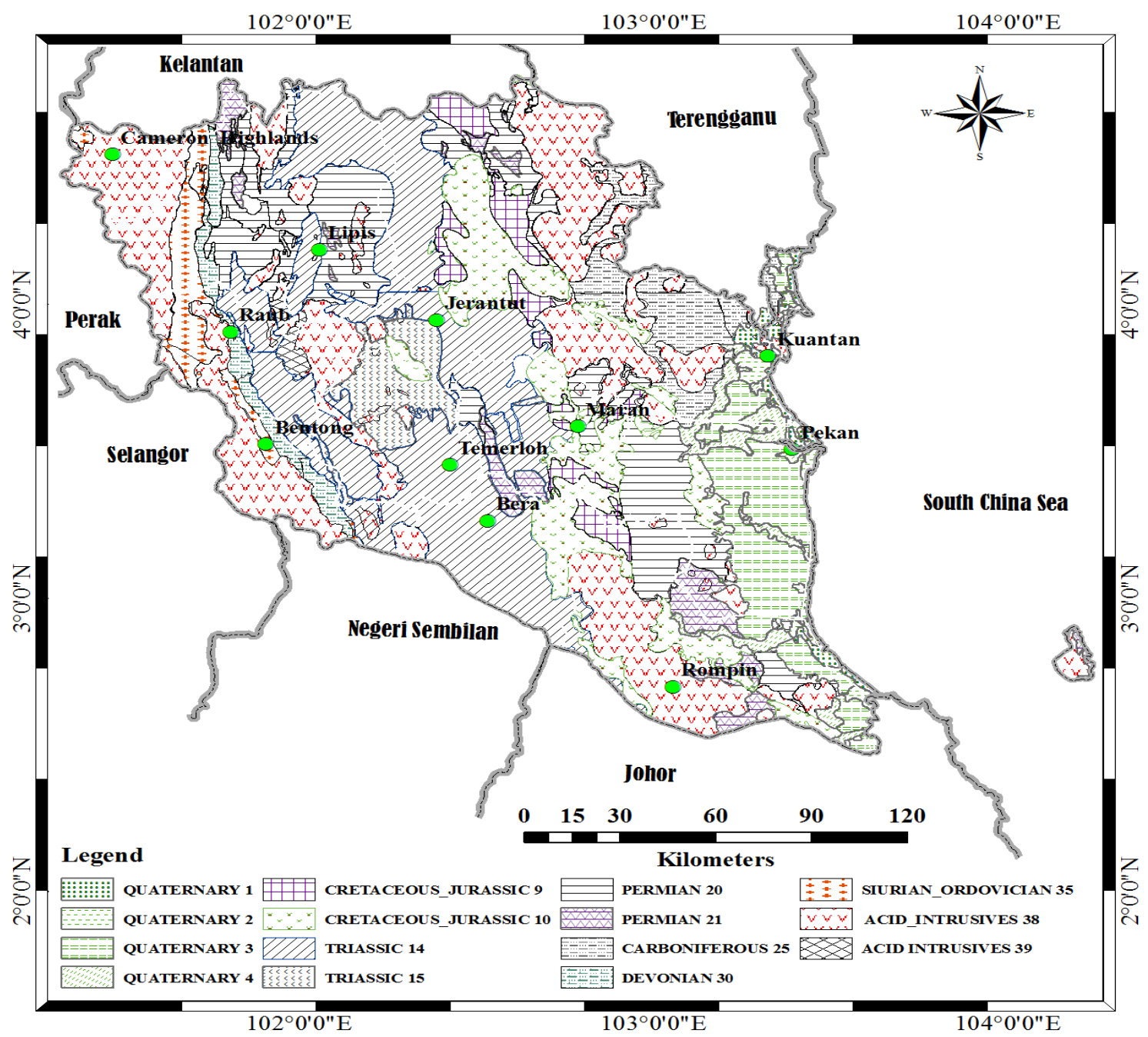

Fig. 1. Geological formations of Pahang state [13]. 
Terrestrial gamma dose rate (TGDR) was measured $1 \mathrm{~m}$ above the soil from various locations. The measurement points were chosen based on the geological formation (Fig. 1) and soil types (Table 1.) of the area. The TGDR measurements were taken using a gamma-ray detector at each point, recorded with a Global Positioning System Receiver Garmin (GPSmap 76) from the location of the latitude and longitude of each surveying point. The average value was recorded from four measurements around each point. The detector used was model 19, micro Roentgen $(\mu \mathrm{R})$ meter, manufactured by Ludlum, USA. It uses sodium iodide (NaI) crystal doped with thallium ( $\mathrm{Tl}$ ) as an activator. The approximate linear energy of the detector falls between $0.80 \mathrm{MeV}$ and $1.2 \mathrm{MeV}$, this ranges covers the majority of significant gamma-ray emissions from terrestrial sources. The detection of gamma-rays from cosmic rays is negligible due to the detector's low response to high-energy Gamma radiation [1] and [12].

Table 1. Soil types in Pahang State

\begin{tabular}{|c|c|c|c|}
\hline $\mathbf{S} / \mathbf{N}$ & Soil type & Local name & FAO / UNESCO \\
\hline 1 & $(1)$ & Rudua-Rusila & HumicPodzols-Dytstric Fluvisols \\
\hline 2 & (2) & Keranji & Thionic Fluvisol \\
\hline 3 & (8) & Beriah-lempung organan \& muk & Organic Clay and Muck \\
\hline 4 & (9) & Lempung organan and muck & Organic clay and muck \\
\hline 5 & (10) & Tanah Gambut (Peat) & Dystric Histosols \\
\hline 6 & (11) & Telemong Akob- Tanah Lanar & Dystric Fluvisols - Dystric Gleysol \\
\hline 7 & $(16)$ & Sogomana-sitiawan-manik & Gleyic Acrisols \\
\hline 8 & (18) & Holyrood lunas & Xanthic Ferrasols -Dystric Gleysols \\
\hline 9 & (19) & Kelau-Kawang & Ferric Acrisols-Haplic Acrisol \\
\hline 10 & (20) & Harimau Tampoi & Ferric Acrisols -Ferric Acrisols \\
\hline 11 & (21) & Batu Anam-Durian & Orthic Acrisols-Ferric Acrisols \\
\hline 12 & $(22)$ & Batu Anam-Melaka -Tavy & OrthicAcrisols-Plinthic Ferralsols \\
\hline 13 & $(23)$ & Marang-Apek & Plinthic Acrisols-Plinthic Acrisols \\
\hline 14 & $(25)$ & Gajah Mati-Munchong-Malacca & $\begin{array}{l}\text { PlinthicFerralsols-Plinthic Ferralsols- Plinthic } \\
\text { Ferralsols }\end{array}$ \\
\hline 15 & $(26)$ & Durian-Malacca-Tavy & $\begin{array}{l}\text { FerricAcrisols-Plinthic Ferralsols-Plinthic } \\
\text { Ferralsols }\end{array}$ \\
\hline 16 & $(27)$ & Munchong-Seremban & Orthic Ferralsols \\
\hline 17 & (28) & Munchong-Serdang & OrthicFerralsols-Ferric Acrisols \\
\hline 18 & (29) & Bungor-Munchong & FerricAcrisols-Orthic Ferralsols \\
\hline 19 & $(30)$ & Serdang-Bungor-Munchong & FerricAcrisols-Ferric Acrisols-Orthic Ferrasols \\
\hline 20 & (31) & Rengam-Jerangau & DystricNitosols-Orthic Ferrasols \\
\hline 21 & $(32)$ & Rengam-Tampin & DystricNitosols-Ferric Acrisols \\
\hline 22 & (33) & Segamat-Katong & Rhodic Ferralsols-Xanthic ferralsols \\
\hline 23 & (34) & Kuantan & Rhodic Nitosols \\
\hline 24 & (35) & Prang & Rhodic Ferralsols \\
\hline 25 & $(37)$ & Langkawi & Ferric Acrisols-DystricNitosols \\
\hline 26 & (38) & Durian-Munchong-Bungor & $\begin{array}{l}\text { FerricAcrisols-Orthic Ferralsols- Ferric } \\
\text { Acrisols }\end{array}$ \\
\hline 27 & $(39)$ & Bungor durian & Ferric Acrisol- Orthic Ferrasols \\
\hline 28 & (41) & Jempol & Rhodic Ferralsols \\
\hline 29 & (43) & Kuala berang-Kedah-Serdang & Latosols \\
\hline 30 & (45) & Serdang-Kedah & Ferric Acrisols \\
\hline 31 & $(47)$ & Rengam-Bukit Temiang & Dystric Nitosols \\
\hline 32 & (48) & Tanah Curam & Steep land \\
\hline 33 & (49) & Tanah Bandar & Urban Land \\
\hline 34 & (50) & Tanah lombong & Mined land \\
\hline
\end{tabular}

\section{Results and Discussion}

Fig. 2 shows the box plot for gamma dose rate and geological formation in the study area. The box plot shows the median values (the centre line of the box) of all the geological formations are less than $200 \mathrm{nGy}$ $\mathrm{h}^{-1}$ except for acid intrusive (38) and (39) which has higher values. Geological formations (4), (35), (38) and (39) have almost a symmetric box indicating that their values are almost normally distributed. Geological 
formation (10) and (14) have both outliers (o) and extreme outliers (*) with values greater than 1.5 times and 3 times the interquatile range (length of the box) respectively. Acid intrusive formation (39) has the highest mean value and quaternary (3) geological formation has the lowest mean value of dose rate.

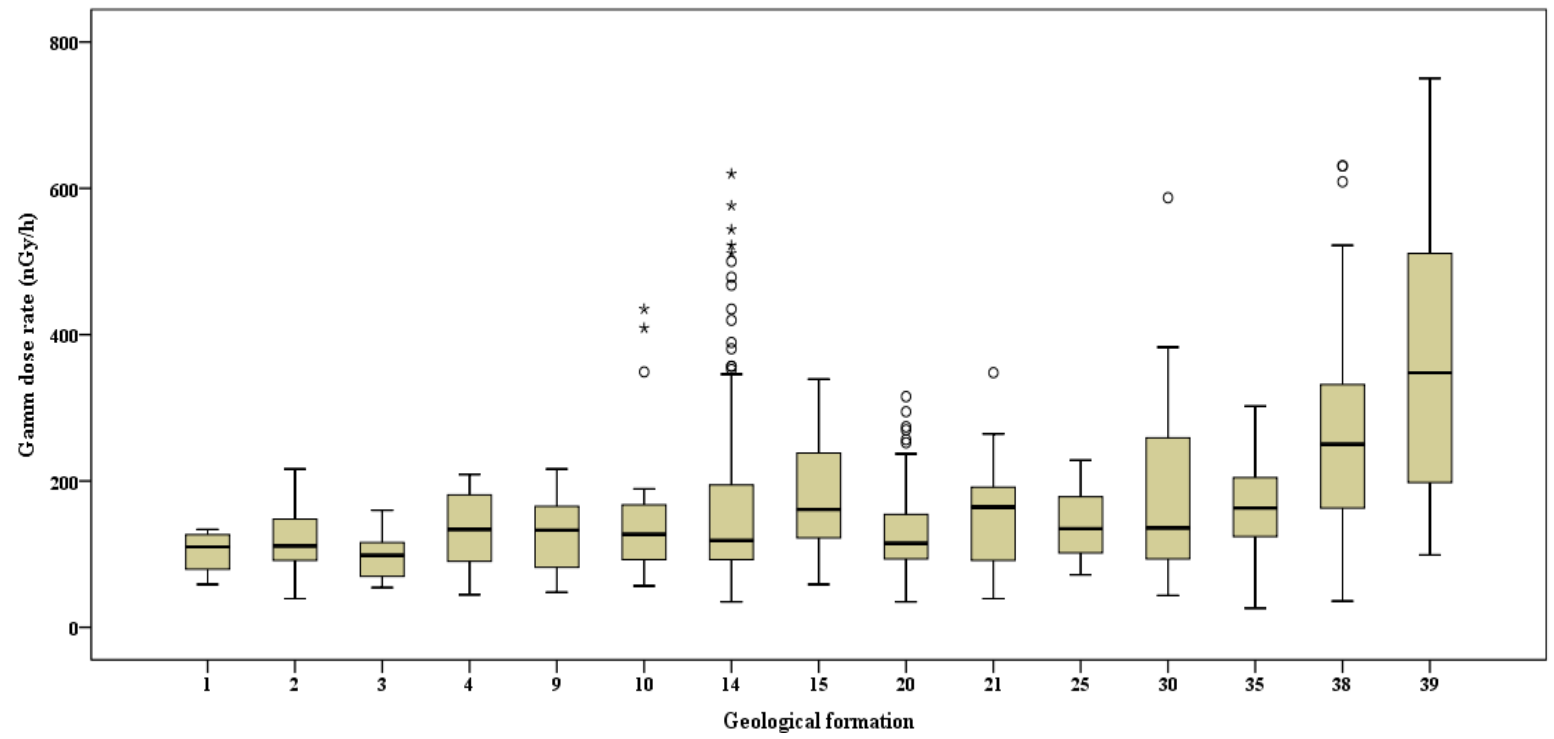

Fig. 2. Box plot for TGDR and geological formation in the study area.

Fig. 3 shows the box plot for gamma dose rate and soil types in the study area. The plot shows some outliers and extreme outliers particularly soil type (38) which has the highest number of measurement. Majority of the plots are positively skewed. This explains the positive skewness of the measured data in the study area. Soil type (48) Steep land and soil type (31) DystricNitosols-Orthic Ferrasols, has the minimum and the maximum values of the TGDR in the area as shown by the lower and upper whiskers from their respective box plots.

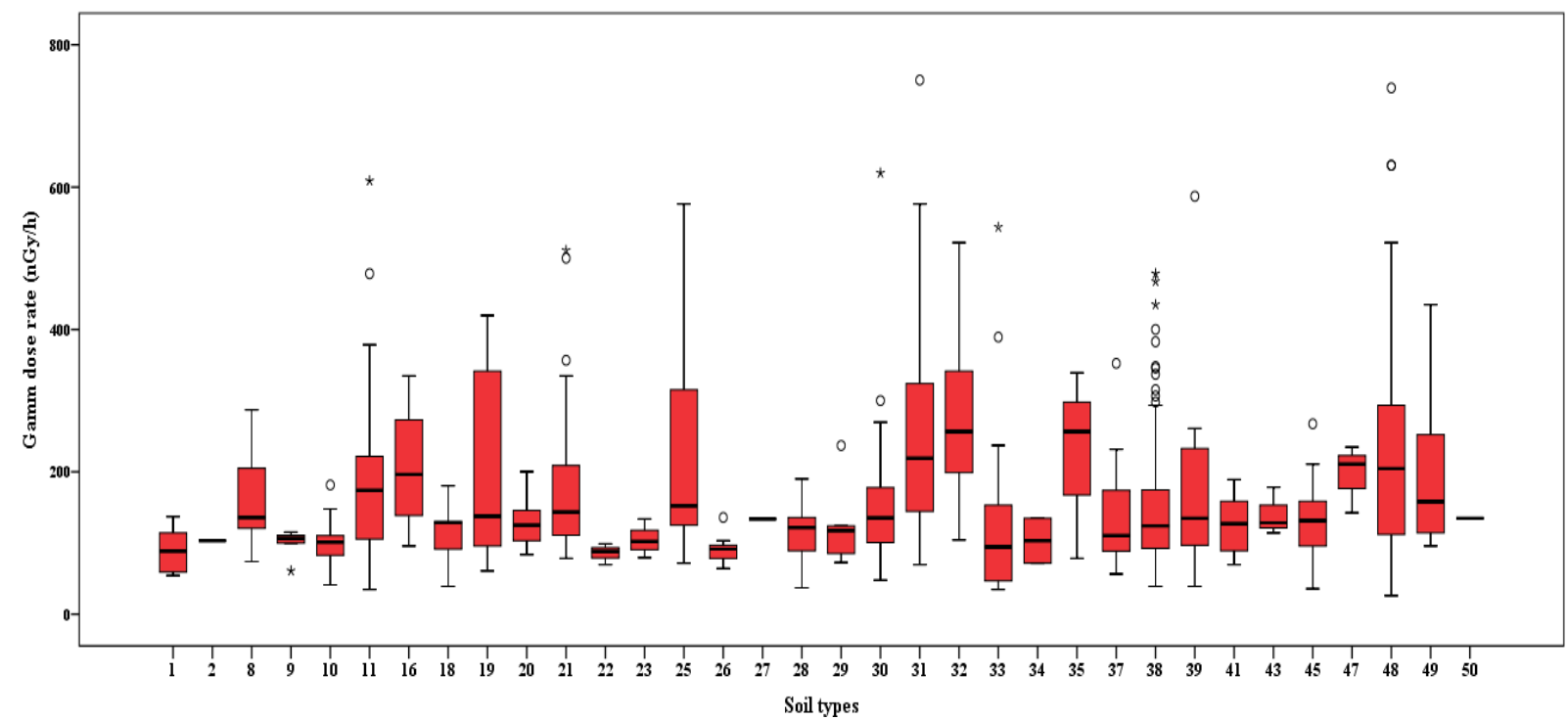

Fig. 3. Box plot for TGDR and soil type in the study area.

\section{Statistical Prediction}

Statistical prediction model is important in other to predict terrestrial gamma dose rate with a minimum 
field work. In this study the prediction was carried out base on the geological formations and soil types in the area. Multi regression analysis was performed on the measured TGDR values for the geology and soil where a linear regression equation was obtained. The result of multi-regression analysis for the prediction of terrestrial gamma radiation dose rate (TGDR) based on geological formations and soil types are given in Tables 2,3 and 4.

Table 2. Prediction Model Summary

\begin{tabular}{|l|l|l|l|l|}
\hline Model & R & R Square & Adjusted R Square & Std. Error of the Estimate \\
\hline 1 & 0.883 & 0.779 & 0.778 & 98.919 \\
\hline
\end{tabular}

Table 3. ANOVA Results for the Prediction Model

\begin{tabular}{|ll|l|l|l|l|l|}
\hline Model & & Sum of Squares & df & Mean Square & F & Sig.(P) \\
\hline 1 & Regression & 21998381 & 2 & 10999190 & 1124 & 0.000 \\
& Residual & 6242827 & 638 & 9785 & & \\
& Total & 28241208 & 640 & & & \\
\hline
\end{tabular}

Table 4. Coefficients of the Prediction Model

\begin{tabular}{|c|c|c|c|c|c|c|}
\hline \multirow{2}{*}{\multicolumn{2}{|c|}{ Model }} & \multicolumn{2}{|c|}{ Unstandardized Coefficients } & \multirow{2}{*}{$\begin{array}{l}\text { Standardized Coefficients } \\
\text { Beta }\end{array}$} & \multirow{2}{*}{$\begin{array}{l}\mathrm{t} \\
\text { Tolerance } \\
\end{array}$} & \multirow{2}{*}{$\begin{array}{l}\text { Sig.(P) } \\
\text { VIF }\end{array}$} \\
\hline & & B & Std. Error & & & \\
\hline 1 & $\begin{array}{l}\text { SOIL } \\
\text { GEO }\end{array}$ & $\begin{array}{l}0.359 \\
0.660\end{array}$ & $\begin{array}{l}0.073 \\
0.072\end{array}$ & $\begin{array}{l}0.311 \\
0.580\end{array}$ & $\begin{array}{l}4.925 \\
9.176\end{array}$ & $\begin{array}{l}0.000 \\
0.000\end{array}$ \\
\hline
\end{tabular}

Table 2 the prediction model summary the value of the correlation coefficient " $R$ " is seen to be 0.883 $(88.3 \%)$ which shows that a good correlation exits between the dependent variable (TGDR) and the two independent variables (TGDR base on geological formations and soil types). Higher value of " $R$ " indicates that the predicted values are more closely correlated to the dependent variable (i.e., the greater the value of $R$, the better the independent variables are at predicting the dependent variable). A value of 0.883 , in this case, indicates a good level of prediction. The adjusted $R$ square value of 0.778 indicates that the independent variables (soil and geology) explain $77.8 \%$ of the variability of our dependent variable (TGDR).

Table 3 the ANOVA results for the model shows that the independent variables statistically significantly predict the dependent variable with $F(2,638)=1124$, Sig. $(P)<0.001$ that satisfied the null hypothesis (i.e., the regression model is a good fit of the data).

Table 4 the coefficient of the model shows the standardized coefficient (Beta) which gives the coefficient for the linear regression equation for the model. The general linear equation model for the prediction of TGDR base on geological formation and soil types is therefore given as;

$$
\text { Predicted TGDR }=0.580\left(G_{D}\right)+0.311\left(S_{D}\right)
$$

where $G_{D}$ is TGDR on geological formation and $S_{D}$ is TGDR on Soil type

The predicted mean TGDR for Pahang state is found to be $157 \mathrm{nGy} \mathrm{h}^{-1}$. This value compares well with the measured mean TGDR, which is $176 \mathrm{nGy} \mathrm{h}^{-1}$, it is about $11 \%$ lower than the measured mean TGDR. This level of error is acceptable for environmental radiological protection purposes [14]. The highest TGDR predicted is $296 \mathrm{nGy} \mathrm{h} \mathrm{h}^{-1}$ and the highest measured TGDR due to geology and soil combination is $631 \mathrm{nGy}$ 
$\mathrm{h}^{-1}$. All are coming from acid intrusive geological formation (39). The lowest predicted TGDR is $87 \mathrm{nGy} \mathrm{h}^{-1}$ while the lowest measured mean dose rate due to geology and soil is $83 \mathrm{nGy} \mathrm{h}^{-1}$, all coming from quaternary geological formation and from the soil type (1) HumicPodzols-Dytstric Fluvisols. All values compares well to each other.

Table 5 shows, eighty five combinations of soil types and geological formations in Pahang state with the results of the hypothesis testing for the prediction model obtained.

Table 5. Combination of Geological Formations and Soil Types with Hypothesis Test

\begin{tabular}{|c|c|c|c|c|c|c|c|}
\hline $\begin{array}{l}\text { Geological } \\
\text { formation } \\
G_{i}\end{array}$ & $\begin{array}{c}\text { Soil } \\
\text { type } \\
S_{i}\end{array}$ & $\begin{array}{l}\text { Measured } \\
D_{G, S}\left(\mathrm{nGy} \mathrm{h}^{1}\right) \\
\qquad G_{i} \cap S_{i}\end{array}$ & $\begin{array}{l}\text { Predicated } \\
D_{G, S} \\
\left(n G y h^{1}\right)\end{array}$ & $\begin{array}{l}\text { Mean } \\
\text { Difference } \\
\left(\mathrm{nGy} \mathrm{h}^{1}\right)\end{array}$ & T-test & $\begin{array}{l}\text { Sig. } \\
\text { (P) }\end{array}$ & Hypothesis \\
\hline 1 & 38 & 127 & 111 & 16 & 2.220 & 0.2 & Accepted \\
\hline 2 & 1 & 103 & 99 & 4 & 0.174 & 0.8 & Accepted \\
\hline 2 & 10 & 109 & 105 & 4 & 0.342 & 0.7 & Accepted \\
\hline 2 & 11 & 195 & 130 & 65 & 3.075 & 0.2 & Accepted \\
\hline 2 & 18 & 110 & 108 & 2 & 0.062 & 0.9 & Accepted \\
\hline 3 & 1 & 83 & 87 & -4 & -0.445 & 0.6 & Accepted \\
\hline 3 & 9 & 96 & 90 & 6 & 0.327 & 0.7 & Accepted \\
\hline 3 & 30 & 137 & 112 & 25 & 1.096 & 0.4 & Accepted \\
\hline 4 & 8 & 194 & 133 & 61 & 4.163 & 0.1 & Accepted \\
\hline 4 & 11 & 102 & 137 & -35 & -1.205 & 0.3 & Accepted \\
\hline 4 & 30 & 134 & 131 & 3 & 0.082 & 0.9 & Accepted \\
\hline 4 & 49 & 144 & 141 & 3 & 0.065 & 0.9 & Accepted \\
\hline 9 & 11 & 130 & 134 & -4 & -0.108 & 0.9 & Accepted \\
\hline 9 & 28 & 125 & 111 & 14 & 0.814 & 0.4 & Accepted \\
\hline 10 & 8 & 134 & 141 & -7 & -3.328 & 0.1 & Accepted \\
\hline 10 & 11 & 161 & 146 & 15 & 0.461 & 0.6 & Accepted \\
\hline 10 & 30 & 103 & 139 & -36 & -2.188 & 0.1 & Accepted \\
\hline 10 & 38 & 116 & 137 & -21 & -1.003 & 0.3 & Accepted \\
\hline 10 & 41 & 167 & 128 & 40 & 1.824 & 0.3 & Accepted \\
\hline 10 & 48 & 144 & 162 & -19 & -0.418 & 0.6 & Accepted \\
\hline 14 & 10 & 90 & 126 & -36 & -3.369 & 0.0 & Rejected \\
\hline 14 & 11 & 174 & 151 & 23 & 2.244 & 0.0 & Rejected \\
\hline 14 & 19 & 198 & 159 & 39 & 0.718 & 0.4 & Accepted \\
\hline 14 & 20 & 118 & 135 & -17 & -1.560 & 0.2 & Accepted \\
\hline 14 & 21 & 181 & 153 & 28 & 1.273 & 0.2 & Accepted \\
\hline 14 & 22 & 86 & 119 & -33 & -3.903 & 0.0 & Accepted \\
\hline 14 & 23 & 105 & 126 & -21 & -1.320 & 0.3 & Accepted \\
\hline 14 & 26 & 91 & 121 & -30 & -5.282 & 0.0 & Rejected \\
\hline
\end{tabular}




\begin{tabular}{|c|c|c|c|c|c|c|c|}
\hline 14 & 28 & 102 & 129 & -26 & -3.081 & 0.0 & Rejected \\
\hline 14 & 29 & 101 & 131 & -31 & -1.313 & 0.4 & Accepted \\
\hline 14 & 30 & 198 & 145 & 53 & 0.835 & 0.4 & Accepted \\
\hline 14 & 31 & 134 & 179 & -45 & -1.630 & 0.2 & Accepted \\
\hline 14 & 32 & 254 & 180 & 74 & 1.937 & 0.0 & Accepted \\
\hline 14 & 33 & 138 & 139 & -1 & -0.017 & 0.9 & Accepted \\
\hline 14 & 37 & 115 & 140 & -25 & -1.186 & 0.2 & Accepted \\
\hline 14 & 38 & 163 & 142 & 20 & 1.284 & 0.2 & Accepted \\
\hline 15 & 11 & 203 & 164 & 39 & 0.527 & 0.6 & Accepted \\
\hline 15 & 21 & 136 & 165 & -29 & -1.504 & 0.3 & Accepted \\
\hline 15 & 31 & 234 & 191 & 43 & 2.279 & 0.1 & Accepted \\
\hline 15 & 38 & 160 & 155 & 5 & 0.182 & 0.8 & Accepted \\
\hline 15 & 41 & 114 & 146 & -32 & -0.711 & 0.6 & Accepted \\
\hline 15 & 45 & 185 & 150 & 36 & 1.069 & 0.3 & Accepted \\
\hline 15 & 48 & 165 & 181 & -16 & -0.581 & 0.5 & Accepted \\
\hline 20 & 11 & 158 & 137 & 21 & 0.924 & 0.3 & Accepted \\
\hline 20 & 25 & 180 & 151 & 29 & 0.399 & 0.7 & Accepted \\
\hline 20 & 28 & 131 & 114 & 17 & 3.831 & 0.1 & Accepted \\
\hline 20 & 29 & 136 & 116 & 20 & 0.562 & 0.6 & Accepted \\
\hline 20 & 30 & 97 & 130 & -33 & -1.977 & 0.1 & Accepted \\
\hline 20 & 31 & 197 & 164 & 33 & 0.946 & 0.5 & Accepted \\
\hline 20 & 38 & 114 & 127 & -13 & -1.501 & 0.1 & Accepted \\
\hline 20 & 41 & 99 & 119 & -20 & -2.012 & 0.2 & Accepted \\
\hline 20 & 48 & 84 & 153 & -70 & -5.269 & 0.0 & Rejected \\
\hline 20 & 49 & 131 & 140 & -10 & -1.051 & 0.4 & Accepted \\
\hline 21 & 11 & 146 & 149 & -2 & -0.086 & 0.9 & Accepted \\
\hline 21 & 31 & 169 & 176 & -7 & -0.330 & 0.7 & Accepted \\
\hline 21 & 38 & 181 & 140 & 41 & 0.728 & 0.5 & Accepted \\
\hline 21 & 48 & 192 & 166 & 27 & 24.72 & 0.0 & Rejected \\
\hline 25 & 31 & 151 & 170 & -19 & -0.832 & 0.4 & Accepted \\
\hline 25 & 34 & 103 & 117 & -13 & -0.427 & 0.7 & Accepted \\
\hline 25 & 38 & 108 & 134 & -25 & -1.122 & 0.3 & Accepted \\
\hline 25 & 43 & 140 & 130 & 11 & 0.543 & 0.6 & Accepted \\
\hline 30 & 11 & 151 & 164 & -13 & -0.373 & 0.7 & Accepted \\
\hline 30 & 38 & 174 & 155 & 19 & 0.269 & 0.8 & Accepted \\
\hline 30 & 39 & 305 & 166 & 139 & 0.955 & 0.4 & Accepted \\
\hline 30 & 45 & 116 & 150 & -34 & -1.594 & 0.2 & Accepted \\
\hline
\end{tabular}




\begin{tabular}{|c|c|c|c|c|c|c|c|}
\hline 30 & 48 & 172 & 181 & -9 & -0.345 & 0.7 & Accepted \\
\hline 35 & 38 & 166 & 146 & 19 & 1.316 & 0.2 & Accepted \\
\hline 35 & 48 & 167 & 172 & -5 & -0.228 & 0.8 & Accepted \\
\hline 38 & 8 & 223 & 203 & 20 & 0.406 & 0.7 & Accepted \\
\hline 38 & 11 & 229 & 208 & 21 & 0.406 & 0.6 & Accepted \\
\hline 38 & 16 & 206 & 217 & -11 & -0.232 & 0.8 & Accepted \\
\hline 38 & 21 & 185 & 209 & -24 & -1.273 & 0.3 & Accepted \\
\hline 38 & 25 & 233 & 222 & 10 & 0.097 & 0.9 & Accepted \\
\hline 38 & 30 & 240 & 201 & 39 & 0.848 & 0.4 & Accepted \\
\hline 38 & 31 & 251 & 235 & 16 & 0.652 & 0.5 & Accepted \\
\hline 38 & 32 & 291 & 236 & 55 & 2.639 & 0.0 & Rejected \\
\hline 38 & 38 & 275 & 198 & 76 & 1.904 & 0.1 & Accepted \\
\hline 38 & 45 & 68 & 194 & -126 & -3.918 & 0.1 & Accepted \\
\hline 38 & 47 & 189 & 214 & -25 & -0.546 & 0.6 & Accepted \\
\hline 38 & 48 & 297 & 224 & 72 & 3.457 & 0.0 & Rejected \\
\hline 38 & 49 & 173 & 212 & -39 & -0.853 & 0.4 & Accepted \\
\hline 39 & 11 & 267 & 269 & -2 & -0.039 & 0.9 & Accepted \\
\hline 39 & 31 & 443 & 296 & 147 & 2.252 & 0.0 & Accepted \\
\hline 39 & 38 & 158 & 260 & -102 & -3.763 & 0.1 & Accepted \\
\hline 39 & 48 & 631 & 286 & 345 & 3.171 & 0.1 & Accepted \\
\hline
\end{tabular}

From the table it is seen that only seven (8) out of the eighty five (85) combinations of geological formations and soil types (about 9\%) were rejected by the hypothesis that the prediction model fits. This is a clear indication of the acceptability of the model.

\section{Conclusion}

This study provides the TGDR measurement results for Pahang state Malaysia which were applied to develop a model for statistical prediction of gamma dose rates based on geological formations and soil types. The model was given by the equation TGDR $=0.580\left(\mathrm{G}_{\mathrm{D}}\right)+0.311\left(\mathrm{~S}_{\mathrm{D}}\right)$. The method could be used to predict gamma dose rates in areas with difficult access. Also, it may be used to predict gamma dose rate wherever similar geological formation and soil types exist. The measured and the predicted mean TGDR for Pahang state were found to be $176 \mathrm{nGy} \mathrm{h}^{-1}$ and $157 \mathrm{nGy} \mathrm{h} \mathrm{h}^{-1}$ respectively.

\section{Acknowledgment}

The authors would like to thank Professor Ahmed Termizi Ramli, Dr. Muneer Azeez Saleh, Dr. Nurradden Nasiru Garba and Mr Syazuan Mohammed Sanusi all of the Universiti Teknologi Malaysia (UTM) for their contributions to the development of this paper.

\section{References}

[1] Ramli, A. T., Sallehudin, S., \& Wagiran, H. (2005). Terrestrial gamma radiation dose study to determine the baseline for environmental radiological health practices in Melaka state, Malaysia. Journal of 
Radiological Protection, 25, 435-450.

[2] Eisenbud, M. (1964). Naturally occurring radionuclides in food and water from the Brazilian areas of high radioactivity. Natural Radiation Environment: vol. III (pp. 837- 854). University of Chicago Press.

[3] Malanca, A., Gaidolfi, L., Pessina, V., \& Dallara, G. (1996). Distribution of 226Ra, 232Th and 40K in soils of Rio Grande do Norte (Brazil). Environmental Radioactivity, 3(1), 55-67.

[4] Ramli, A. T. (1997). Enviromental terrestrial gamma radiation dose and its relationship with soil type and underlying geological formation in pontaindistrict Malaysia. Appl. Radiat. Isot., 48(3), 407-412

[5] Roessler, C. E., Mohammed, H., Richards, R., \& Smith, D. L. (1993). Radon source studies in north Florida. Proceedings of the 26th Midyear Topical Meeting. Health Physics Society (pp. 331-347, 24-28).

[6] Radhakrishna et al. (1993). A new natural background radiation area on the southwest cost of India. Health Physics, 65, 390-395.

[7] Roser, F. X., \& Cullen, T. L. (1964). External radiation measurements in high background region of Brazil. The Natural Radiation Environment, 825-836.

[8] Gabdo, H. T., Ramli, A. T., Sanusi, M. S., Saleh, M. A., \& Garba, N. N. (2014). Terrestrial gamma dose rate in Pahang State, Malaysia. J Radioanal Nucl Chem, 299, 1793-1798.

[9] Dragovic, S., Jankovic, L. J., \& Onija, A. (2006). Assessment of gamma dose rates from terrestrial exposure in Serbia and Montenegro. Radiat. Protec. Dosimetry, 121, 297-302.

[10] Karahan, G., \& Bayulken, A. (2000). Assessment of gamma dose rates around Istanbul (Turkey). J. Environ. Activity, 47, 213-221.

[11] Quindos, L., Fernandez, P., Soto, J., Rodenas, C., \& Gomez, J. (1994). Natural radioactivity in spanish soils. Health physics, 66(2), 194-200.

[12] Saleh, M. A., Ramli, A. T., Alajerami, Y., \& Aliyu, A. S. (2013). Assessment of natural radiation levels and associated dose rates from surface soils in Pontian district, Johor, Malaysia. Journal of Ovonic Research, $9(1), 17-27$.

[13] Department of Geological Survey Malaysia. (1985). Geological Map of Peninsular Malaysia 8th.

[14] Ramli, A. T., Ahmad, T. A., \& Lee, M. H. (2003). Statistical prediction of terrestrial gamma radiation dose rate based on geological features and soil types in Kota Tingi district, Malaysia. Applied Radiation and Isotopes, 59, 393-405.

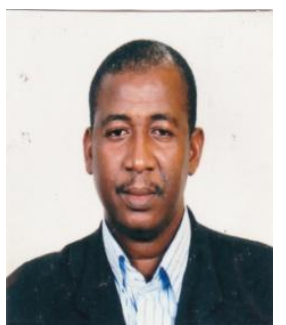

Hamman Tukur Gabdo was born in Adamawa Nigeria 1968. He got the B. Tech physics F.U.T.Y, Nigeria 1991; the Msc nuclear physics A.B.U Zaria, 2011, Nigeria; the Ph.D enviromental nuclear radiation U.T.M Malaysia 2015. He is principal lecturer, Federal College of Education Yola, Nigeria. He is the author of jounal articles including; (1) Gabdo et al (2014). Terrestrial gamma dose rate in Pahang State, Malaysia. J Radioanal Nucl Chem 299:1793-1798, Gabdo et al, 2015. (2) Natural Radioactivity Measurements in Pahang State,Malaysia. Isotopes in Environmental and Health Studies. His reseach interest are radiation Physics. Dr. Gabdo is the member science teachers association of Nigeria. 